\title{
The Genus Licuala Wurmb (Arecaceae) in Java
}

\author{
Etti Sartina Siregar ${ }^{\left.{ }^{*}\right)}$ dan Sri Sudarmiyati Tjitrosoedirdjo²) \\ 1)Departement of Biology, Faculty of Mathematics and Natural Sciences, \\ University of Sumatra Utara, Medan 20155 \\ ${ }^{2}$ Departement of Biology, Faculty of Mathematics and Natural Sciences, \\ Bogor Agriculture Institute, Bogor 16680
}

Diterima 07-12-2010 Disetujui 07-03-2011

\begin{abstract}
The comprehensive revision of the genus has been done in the Malay Peninsula, New Guinea, Sumatra and Kalimantan. In Java, the revision of Licuala has never been recently completed. This study was based on morphological characters of specimens which are preserved in Herbarium Bogoriense. The several living collections cultivated in Bogor Botanical Garden were studied. The aim of this study is to ascertain the correct names and improve the species delimitation of Licuala in Java. The result shows that there are three species of Licuala in Java. They are $L$. gracilis, $L$. pumila and $L$. spinosa. Two previously known species have been placed into synonymies; L. flabellum to L. gracilis, and L. spectabilis to L. spinosa. Licuala gracilis is endemic for west Java.
\end{abstract}

Keywords: Arecaceae, Java, Licuala

\section{INTRODUCTION}

Licuala is a genus belonging to the family Arecaceae (a conserved alternative name for the Palmae), subfamily Coryphoideae, tribe Corypheae and sub tribe Livistoninae (Uhl \& Dransfield, 1987). It is a small to medium sized tree palm, rarely arborescent and easily recognized by the wedge-shaped fronds with segments that split to the hastula. Naturally, all species of Licuala are understorey palms. In general, the genus does not survive under open conditions and commonly found in the lowland forest. However, some species are also found in the other forest types, such as $L$. spinosa in open moist place and L. glabra in the hill stations. Traditionally, some species of this genus such as $L$. acutifida, L. grandis, L. paludosa and $L$. spinosa, are used as ornaments, decoration, roofing, food-wrappers, walking sticks, binding, making hats and eaten as vegetable (Burkill, 1935; Whitmore, 1973; Dransfield, 1976; Saw, 1997).

The genus consists of 141 species, occuring from Vanuatu, the Solomon Islands, New Guinea, Australia, Indonesia, the Philippines, Malaysia, Thailand, Cambodia, Laos, Vietnam, China (southern part),

"Telp: +6281264852784

Email: ettisartina@yahoo.com
Myanmar, Bangladesh, and India (north-eastern part and the Andaman Islands). The centre of species diversity consider is at the two main areas, one within the Sunda Shelf in Malaya and Borneo and the other at the Sahul Shelf on the island of New Guinea (Saw, 1997; Saw et al., 2003).

The name Licuala is derived from the Makassar (Celebes) name 'leko wala' (Backer, 1936). It was first described by Rhumpius (1741), in the Herbarium Amboinense as Licuala arbor. As this name was preLinnean, so the name $L$. spinosa as was described by Wurmb (1780), was accepted by International Code of Botanical Nomenclature or ICBN (Greuter et al., 2000). Thus, $L$. spinosa is regarded as the genus type of Licuala.

The genus contains wide morphological variations and these cause a serious problem to the researcher in the process of revising. These morphological variations were easily observed in the field rather than through herbarium specimens. Thus, taxonomic study is based mainly on the data gained from fieldworks, such as inflorescences and flowers, which are not always found in the herbarium specimens.

The last comprehensive revision of the genus in the Malay Peninsula has been done by Saw (1997), 
in New Guinea by Barford (2000), in Sumatera by Ardan (2000) and in Kalimantan by Batoro (2001). In Java, the revision of Licuala has never been recently completed. According to Blume (1836), there are two species of Licuala in Java, L. gracilis BI. and L. pumila BI. Miquel (1851), reported 3 species, L. pumila BI., L. spinosa Wurmb and L. spectabilis Miq. Koorders (1913), reported two species, L. pumila Bl. and L. spinosa Wurmb. Backer \& Bakhuizen van den Brink Jr. (1968), recognized only two species of Licuala in Java, $L$. spinosa Wurmb and L. pumila BI. In Bogor Botanical Garden, there are two clusters of living collection, which are believed (to be) of Ujung Kulon original and identified as $L$. flabellum (Anonymous, 1985). Interestingly, this species was previously described by Martius (1838), that was found in the wild of Celebes, however no other collections were found.

Therefore, it is considered essential to proceed the study of this genus in Java to ascertain the correct names and improve the species delimitation. The study is based on the herbarium materials from Herbarium Bogoriense (BO) and fresh materials from Bogor Botanical Garden.

\section{MATERIALS AND METHODS}

Specimens of Licuala which were collected from Java by the previous collector, fresh materials from Bogor Botanical Garden and some other areas in Java were the major materials for examinations. Collecting method followed Dransfield (1986). Morphological species concept is adopted in this study, following Dransfield (1999). The terminologies followed Stearn (1966), Uhl and Dransfield (1987), Dransfield and Beentje (1996). The basic description follows Uhl and Dransfield (1987), Saw (1997), Barfod and Saw (2002).

\section{RESULTS AND DISCUSSIONS}

Vegetative Organs. Licuala is rarely treelike, small to medium sized, acaulescent to shrubby, solitary or clustered. Licuala pumila is solitary, whereas $L$. gracilis and $L$. spinosa are clustered. Licuala spinosa is the tallest within the genus and almost treelike. Licuala pumila is almost acaulescent.

Petioles are usually with spines. The spines are found almost at the whole length of the petiole in $L$. spinosa, about half of the petiole in $L$. gracilis and $L$. pumila. Fronds are orbicular in L. gracilis and L. pumila, but peltate-orbicular in $L$. spinosa. The base of most fronds is equal but unequal in L. gracilis. The leaves are always split into many segment. Central segment is usually entire, except $L$. gracilis, which has bifid central segment. The central segment is slightly larger than the rest in $L$. gracilis or about equal in size with the lateral segment in $L$. spinosa and $L$. pumila.

Generative Organs. The inflorescence pattern provide some good characters in distinguishing the species (Figure 1). The inflorescence is erect to patent, longer than petiole in L. spinosa or shorter than petiole in $L$. gracilis and L. pumila. The inflorescence varies in the number of branching orders, from one in L. pumila
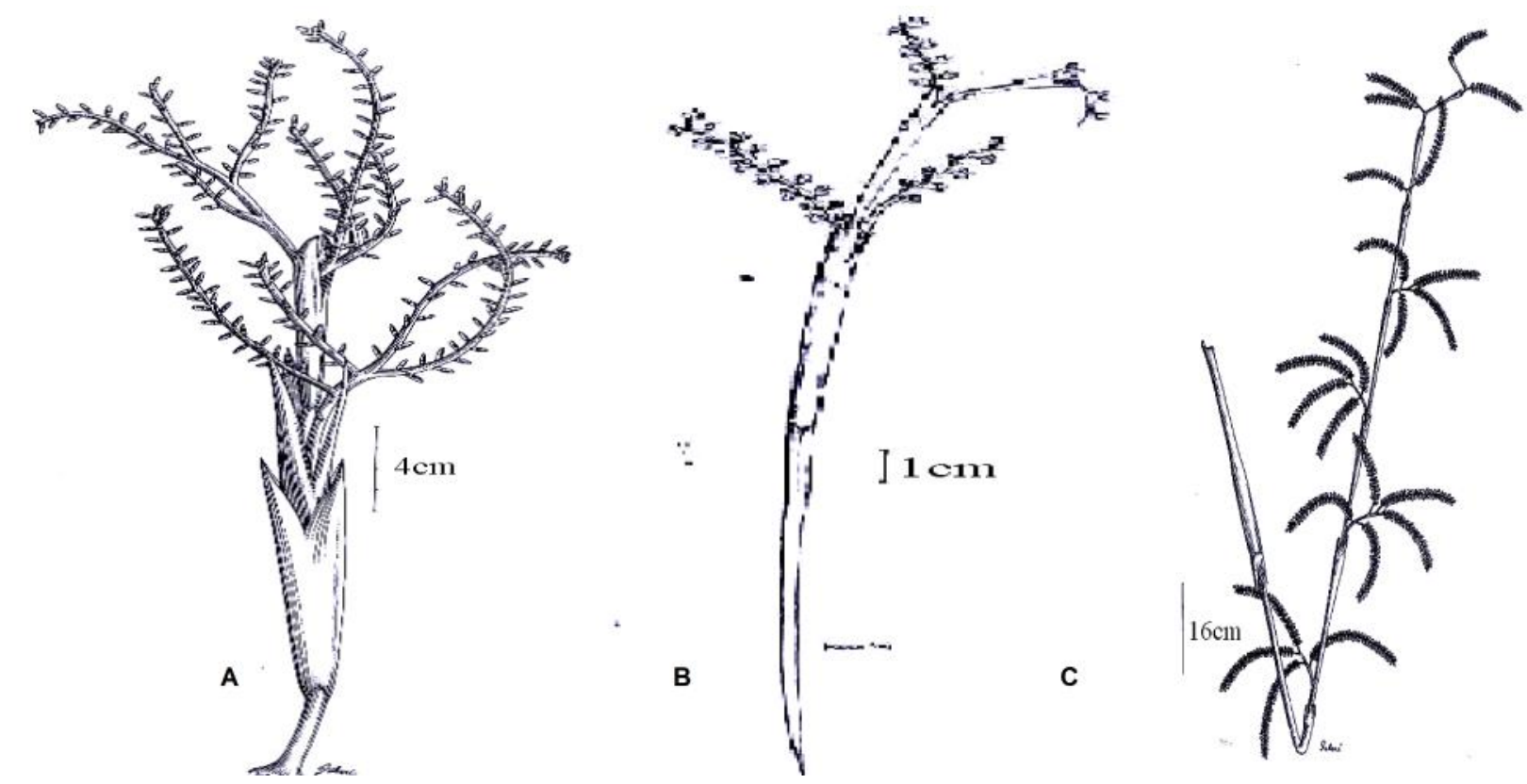

Figure 1. Inflorescence patterns of Licuala in Java: A. L. gracilis (from Dransfield 1498); B. L. pumila (from JPM 7723); C. L. spinosa (from Koorders 25443ß, Dransfield 3525) 
to two in L. spinosa and L. gracilis. Peduncular bract is present or sometimes absent in L. Spinosa, but it is completely absent in L. gracilis as well as in L. pumila.

Flowers are hairy or glabrous. The flowers of $L$. spinosa is hairy, but glabrous in L. gracilis and L. pumila. The flowers are sessile and solitary in L. Pumila, whereas in L. gracilis and L. spinosa are arranged in solitary or group.

The shape of calyx varies from cylindrical to cyathiform in L. spinosa, campanulate in L. pumila and tubular in L. gracilis. Corolla usually exceeding the calyx, tubular at the base, thick with lobe acute, except in L. gracilis which has blunt apex. Staminal ring is present in all species. Ovary shape are varies, from turbinate in $L$. pumila and $L$. spinosa to cone shape in L. gracilis. It is glabrous in all species under study.

Fruit mostly globose with smooth surface. Immatured fruits are pink or cherry red in L. gracilis, whereas the other species have green immature fruits. The seeds have the same shape as the fruits. The surface is always smooth.

\section{TAXONOMY}

\section{Key To The Species Of Licuala In Java}

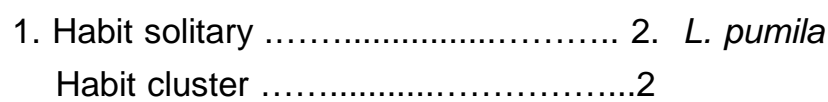

2. Inflorescence longer than petiole, outer surface of calyx and corolla hairy, young fruit green

..3. L. spinosa

Inflorescence shorter than petiole, outer surface of calyx and corolla glabrous, young fruit pink or cherry red

1. L. gracilis

1. Licuala gracilis Blume.- Figure 2. ustering, gynodioecy plants (the hermaphrodite and female
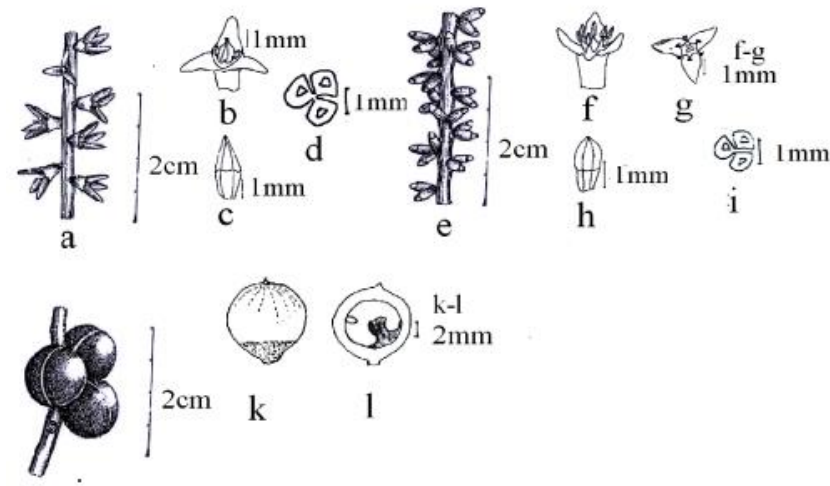

j

Figure 2. L. gracilis (from Dransfield 1498);a-d; female flowers; a. Rachilla with some flower buds; b.open flower bud; c.ovary; d. carpel in cross section. e-i. hermaphprodite flowers; e. rachilla with some flower buds; $f-g$. open flower buds showing the stamens; h. ovary; i. carpel in cross section. j. The apocarpous fruit with three drupes; k. one drupe of fruit; I. one drupe in section inflorescence appear on different individuals). Stem about 1-3 $\mathrm{m}$ tall, to c. $20 \mathrm{~cm}$ diameter, brown, nodes to $1.5 \mathrm{~cm}$ distant. Leaves 10-14 in crown, sheaths to 30 $\mathrm{cm}$ with red - brown fibres; petioles to $120 \mathrm{~cm}$ long, thornly below, 10-12 mm near base, 5-6 toward apex, green; spines along one third to more lenght of petiole, triangular to claws, patent to reflexed, largest near the base; fronds peltate-orbicular, unequal at the base, $\mathrm{c}$. 30-45 cm long, c. 60-80 cm wide, segment c. 9-17 leaflets, the size is not same (wider toward central); lateral segment 2-5 costulate, $25-44 \times 2.5-5 \mathrm{~cm}$; central segment slightly larger than rest, bifid 1/5-1/3 frond lenght, c. 10-14 costulate, c. 30-45 x 7-10 cm. Inflorescences erect, shorter than leaves (very short), c. $15-40 \mathrm{~cm}$ long, extending beyond crown (axilary), branching to two order, bears either entirely female or hermaphrodite flowers at a different individual; prophyll tubular, c. $10-15 \mathrm{~cm}$ long, c. $1.5 \mathrm{~cm}$ wide, coriaceus and flattened at the base, closely sheathing, glabrous at the base and covered with brown hairs at the apex; peduncle c. 10-12 cm long, c. $2-3 \mathrm{~cm}$ wide, covered with sparsely golden brown hairs, peduncular bract lacking; rachis bracts only two, c. $10 \mathrm{~cm}$ long, c. $5 \mathrm{~mm}$ wide; rachillae 8-28, unornamented, c. 8-18 cm long, c. 2-3 mm wide, covered with sparsely golden brown hairs. Flowers sessile, maturing not simultaneously, bud $c$. 4-5 x 2 mm; calyx tubular, c. 2.5-3 x 2-2.5 mm, base thickened, apex trilobed, acuminate, glabrous, yellowish in colours; corolla tripartitus, triangular, c. 3.5-5 x $2 \mathrm{~mm}$, base thickened, glabrous, apex blunt, green yellowish in colour; pistillate flowers solitary, spirally arranged, stays in anthesis for 8 to 10 days; ovary cone shaped, glabrous, to $3.5 \mathrm{~mm}$ long and $1.4 \mathrm{~mm}$ wide; hermaphrodite flowers arranged in group of 2-4 flowers, densely arranged, cincinni 10-15 (c. 4 clusters per $\mathrm{cm}$ ), stay in anthesis for 3 to 4 weeks; staminal ring membranous, c. $1 \mathrm{~mm}$ long, filament subulate, c. $1 \mathrm{~mm}$, base thickened; anther c. $1 \mathrm{~mm}$ long; ovary cone shaped, glabrous, c. $2 \times 0.8 \mathrm{~mm}$, consist of three uniovulate carpels, all three carpels in every flower develop into independent fruits (Figure 2). Fruit globose c. to $9 \mathrm{~mm}$ in diameter, glabrous, pink or cherry red in young and dark red or dark brown when mature (the colour variations occur in the cluster, not in individual), solitary or develops an apocarpous fruit with three drupes (sometimes one flower bears three fruits); seed globose c. 6- $\mathrm{mm}$ in diameter, dark brown and smooth. 
Distribution: Endemic to West Java. Habitat: primary forest, common forest undergrowth component, seashore to mountain about 150-750 m altitude.

Notes: Based on the description of $L$. flabellum in Martius (1838), it has two similar characters with $L$. gracilis, which are the bifid central segment and the inflorescence pattern. This species was described by Martius based on Reinwardt collections which was said originated from Celebes. However, no collections have ever been made. So, there was a collection of this plant from Celebes. The type of $L$. flabellum is kept in Munich. According to Dransfield and Moore (1982), the entire flowers have fallen from the type and in many cases Reinwardt had written the location for his specimens incorrectly. Therefore, so they suggest that the type of L. flabellum has probably been collected from Ujung Kulon. Thus, it is regarded as synonym.

Specimen examined: JAVA: Ujung Kulon - Taman Jaya, Mc Donald \& Afriastini 3378, fr., 18-5-1992 (BO!); G. Payung, Kosterman 21846, fl+fr., 18-11-1960 (BO!, $\mathrm{K}, \mathrm{L}$ ); UNESCO 170, fl. o $^{*}$ fr, s.d. (BO!); G. Kendeng, Kosterman 197, fl. ${ }^{\circ}$, fl. $0^{*}+\mathrm{fr}, 18-11-1960$ (BO!), Dransfield 1433, fl., 15-4-1971 (BO!, I, K, L, Sing), Dransfield 1498, fl. + fr., 21-4-1971 (BO!); Bogor Botanic Garden - cultivated, Etti Siregar 06, fl. ${ }^{\circ}+\mathrm{fr}$ and Etti Siregar 07, fl. ${ }^{\sigma^{x}}+$ fr., 19-6-2003 (BO!).

2. Licuala pumila Blume. - Figure 3. Solitary, acaulescent or with short stem no more than $1 \mathrm{~m}$ tall, about $1.5-2 \mathrm{~cm}$ in diameter, pale brown in colour. Leaves in crown 10-14; sheaths brownish; petioles up to $1.5 \mathrm{~m}$ long, $5-7 \mathrm{~mm}$ wide near base, c. $2.2 \mathrm{~mm}$ wide toward apex, greenish colour, with sparsely spines along less half of petiole, little and turn, claws shape, dense near base of petiole, c. 3-4 mm long and 0.5-1 mm wide. Fronds orbicular, apex shallow dentate, radiately parted 7-14 or more up to 18, c. $33 \mathrm{~cm}$ long, $41 \mathrm{~cm}$ wide, lateral segment $2-4$ costulate, $31 \times 4.5 \mathrm{~cm}$, central seg-

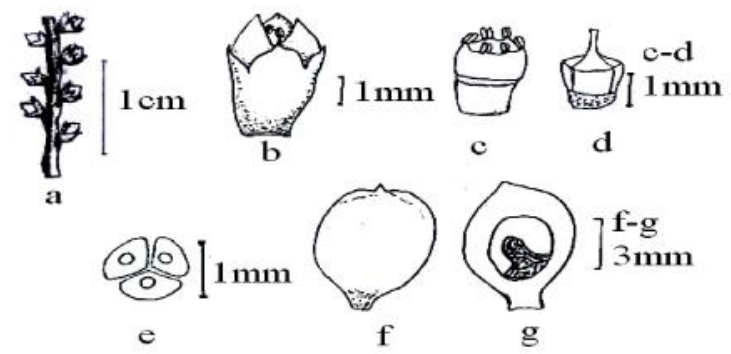

Figure 3. L. pumila (from JPM 7723, Etti Siregar 03); a. Rachilla with some flower buds; b.flower bud; c. calyx and corolla removed revealing the androecium; d. ovary; e. carpel in cross section. f. young fruit; g. young fruit in section ment entire, 4-7 costulate, $33 \times 35 \mathrm{~cm}$. Inflorescences shorter than leaves, erect to patent, $40-55 \mathrm{~cm}$ long with 2-3 partial inflorescences; branching to one order; one to two opposite branching in proximal part, the upper usually occupied by a single rachilla; peduncular bract lacking; peduncle tubular, flattened at the base, c. $10 \mathrm{~cm}$ long, c. $5 \mathrm{~mm}$ wide, glabrous, green in colour; rachis strongly flattened, glabrescent or sometime slightly puberulous; rachillae 4-5, c. 5-10 × $2 \mathrm{~cm}$ size, covered with sparsely golden brown hairs, bracts $\mathrm{c}$. 4-7 cm. Flowers solitary, irregularly, sessile, bud size 6 $x$ 2.5-3 $\mathrm{mm}$; calyx cylindrical to cyathiform, c. $4 \times 3 \mathrm{~mm}$, very slightly three toothed, base thickened, apex acuminate, glabrous, striate externally, green in colour; corolla coriaceus, triangular, tripartitus, c. $5 \times 3 \mathrm{~mm}$, thick, glabrous, base thickened, apex acute, striate externally, deeply sculptured inside, whitish in colour; staminal ring membranous, filament subulate, anthers c. $0.5 \mathrm{~mm}$ long, blunt; ovary turbinate, glabrous, sculptured above, c. $2 \mathrm{~mm}$ long; style subulate, c. $1 \mathrm{~mm}$ long. Fruitsub globose, c. 9-10 $\times$ 8-9 mm, smooth, green in young and orange to red when mature. Seed dark brown, sub globose c. 6-8 mm diameter, smooth.

Distribution: Sumatera and Java. Habitat: Ridge top hill of Dipterocarp forest to lowland Dipterocarp forests, 90 - $1000 \mathrm{~m}$ altitude. Specimen examined: JAVA: Lebak - Sunarari River, Backer6362, fl., 1-1-1913 (BO!), Bakhuizen van den Brink 7946, fr., 1-4-1933 (BO!); Bojong Manik- G. Liman, Koorders 40879â, fr., 14-7 1912 (BO!); Jasinga: Dungus Iwul, Etti Siregar 03, fr., 20-4-2003 (BO!); Steenis 11170, fr., 18-12-1938 (A, BO!, L, Sing), Dransfield 1506, fr., 15-5-1971 (BO!, I); G. Halimun, JPM 7723, fl., th. 2003 (BO!); Cigelung, BeümeeA367, fl., 150, 23-11-1926 (BO!), Backer 10232, fr., 24-11- 1913 (BO!); Janlappa, Meijer 2939, st., 20-81954 (A, BO!, K, L, Sing), Dransfield 991, fr., 11-101970 (BO!); Leuliang, Bakhuizen van den Brink 7915,

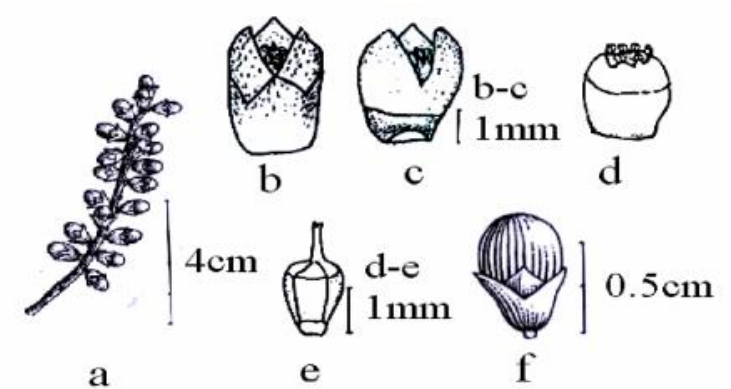

Figure 4. L. spinosa (from Koorders 25443 $\beta$, Dransfield 3525); a. Rachilla with some fruits; b.flower bud; c.flower with calyx removed; d. calyx and corolla removed revealing the androecium; e. ovary; f. young fruit 
st., 30-11-1932 (BO!); Sukabumi: Lengkong, Dransfield 1062, fr., 25-11-1970 (BO!, I, K, L); Cianjur, Backer 23905, fr., 1-4-1918 (BO!).

3. Licuala spinosa Wurmb. -Figure 4. Clustering. Stem to $5 \mathrm{~m}$ or more tall, to c. $23 \mathrm{~cm}$ across. Leaves c. 15 to 17 in crown; sheaths disintegrating into coarse reticulate fibers with dark brown colours; petioles to $2 \mathrm{~m}$ long, edge with black thorn, $10-20 \mathrm{~mm}$ near base, 5-10 $\mathrm{mm}$ toward apex, green to yellow brownish; spines along whole length of petiole, triangular, patent to reflexed, largest near base; fronds peltateorbicular, dark green, c. 50-65 cm long, c. $80-150 \mathrm{~cm}$ wide, segment c. 14-19, all rather the same size; lateral segment 2-5 costulate, 41-51 x 4-9 cm; central segment slightly larger than rest, bipartitus (half to 5-7 cm toward leaf base), sometimes petiolulate, c. 8-14 costulate, c. $52-65$ x 20-23 cm. Inflorescences erect to patent, longer than leaves, extend above the crown, with 7-9 partial inflorescences, c. 1.5-3 m long, branching to two orders; prophyll tubular, c. $20 \mathrm{~cm}$ long or more, c. $1.5-2 \mathrm{~cm}$ wide, coriaceus, flattened, closely sheathing, apex with two keels, densely covered with stellate caducous ferruginous hairs; peduncle $c$. 40-90 cm long, c. 4.5-8 across basally; peduncular bract present, sometimes lacking; rachis rigid, not sinuous; rachis bracts similar to prophyll, c. $20-22 \times 0.7-1.5 \mathrm{~cm}$, rachis bracts mouth splitting neatly in a few lobed; rachillae 4-11 at one partial inflorescence, unornamented, slightly close to or away from mouth of rachis bract, $10-25 \mathrm{~cm}$ long, c. 1.5-3 mm wide, covered with scattered simple brown hairs. Flowers solitary to in group of $2-4$, sessile, densely arranged, cincinni 5-10 per cm, maturing not simultaneously; bud c. 4-5 x 2.5-3 mm; calyx cylindrical to cyathiform, c. $3 \times 2.5-3 \mathrm{~mm}$, base thickened, apex trilobed, acuminate, lobed to about half of calyx length, covered with translucent scattered patent hairs; corolla c. 3.5-4 x $3 \mathrm{~mm}$, thick, densely covered in upper two third with simple translucent hairs, glabrescent toward base, lobes acute c. $1.5 \times 2 \mathrm{~mm}$; staminal ring truncate $\mathrm{c}$. 0.6-0.8 mm high, filament subulate, c.0.3 mm long, anthers c. $0.3 \mathrm{~mm}$ long; ovary glabrous, turbinate, apex truncate, $1.5 \times 1 \mathrm{~mm}$, style filiform, $1 \mathrm{~mm}$ long. Fruit globose c. $6.5-8.5$ x 6-8 mm, glabrous, smooth, immature fruit green and orange to red when mature. Seed globose, smooth, c. 4-6 mm across.

Distribution: Andaman and Nicobar Islands, Thailand, Vietnam, Malaysia, the Philippines, Sumatra,
Java, Borneo. Habitat: Open, slightly swampy ground, lowland alluvial forest, peat and mangrove swamp forest, beach forest, primary forest.

Notes: $L$. spectabilis is a synonym of $L$. spinosa due to several characters such as: segments of frond, the number of inflorescence branching order \% inflorescence is branching to two orders, flowers hairy and sessile. Miquel (1851), based his Licuala spectabilis on specimen collected by Junghuhn from Wijnkoops Bay (close to Pelabuhan Ratu) in Banten, West Java \% where $L$. spinosa is also found. Miquel did not mention where the specimens kept. I have tried to look for the specimen in $\mathrm{BO}$, but I did not find it. However, it was likely that Miquel used the specimen kept in BO when he described this species. Unfortunately, the specimen is now believed to be lost.

Specimen examined: WEST JAVA: P. Panaitan, Waalkes 470, st., 10-9-1951 (BO!); Ujung Kulon, P. Peucang, Dransfield 1478, fl., 18-4-1971 (BO!); Serpong, Backer 17594, fr., s.d. (BO!); Kemayoran, Backer 427, fl.+ fr., s.d. (BO!); Pelabuhan Ratu, Etti Siregar 01, fr., 24-8-2002 (BO!), Dransfield 1098 (BO!, Ithaca); Preanger, Koorders 34586 $\beta$, fl., 14-5-1899 (BO!), Koorders 34589ß, fl., 1-4-1899 (BO!); Cibunar, Dransfield 1472, fl. 17-4-1971 (BO!); Dransfield 1407, fl., 13-41971(BO!); Tanjung Suka, Van Steenis 994, fl., 3-4-1928 (BO!). CENTRAL JAVA: Karimun Jawa, Tg. Gelam, Karta 207, fr., 23-11-1930(BO!), Karta 304, fr., 26-11-1930 (BO!); Jepara, Ngarengan, Koorders 33618 $\beta$, fl. 26-51899 (BO!), Koorders 36846ß, fl., s.d., (BO!), Beümee 3598, fl., Dec. 1918 (BO!); Kedung Jati, Tempuran, Koorders 25443ß, fr., 30-10-1896 (BO!); EAST JAVA: Sukamade, Meru Betiri, Dransfield 3525, fl., 20-5-1973 (BO!, L).

\section{CONCLUSION}

Three species of Licuala in Java are recognized. They are $L$. gracilis, $L$. pumila and $L$. spinosa. Two previously known species have been placed into synonymies; $L$. flabellum to $L$. gracilis, and $L$. spectabilis to $L$. spinosa.

\section{ACKNOWLEDGEMENTS}

This paper forms part of the thesis for master degree at the Bogor Institute of Agriculture in 2004, with financial supports from DIKTI. I would like to thank my supervisors Dr. Sri Sudarmiyati Tjitrosoedirdjo, 
M.Sc. (IPB) and Dr. Johanis P. Mogea (LIPI) for their advice and guidance throughout the thesis. I also would like to thank to the Herbarium Bogoriense for the loans material.

\section{REFERENCES}

Ardan, A.S. 2000. The Sumatran Licuala Revised. Thesis Post Graduate. Bogor: IPB.

Backer, C.A. 1936. Verklarend Woordenbook van Wetenschappelijke Plantennamen. N.V.P. Noordhoff. Batavia Jakarta.

Backer, C.A. \& Bakhuizen Van Den Brink Jr., R.C. 1968. Flora of Java. N.V. Wolter Noordhoff, Groningen. III: 173.

Barfod, A.S. 2000. A new species of Licuala from New Guinea Journal of the International Palm Society 44: 198-201.

Batoro, J. 2001. The Kalimantan genus Licuala. Thesis Post Graduate. Bogor: IPB.

Blume, C.L. 1836. Sive Commentationes Botanicae Imprimis de Plantis Indie Orientalis. Lugduni-Batavorum. In: Rumphia 2: 37-48.

BurkilL, I.H. 1935. A Dictionary of the Economic Product of the Malay Peninsula. Kuala Lumpur. Ministry of Agriculture and Cooperatives.
Dransfield, J. 1976. Palms in the every life of west Indonesia. Principes 20: 39-47.

Dransfield, J. \& Moore, H.E. 1982. The Martian correlation two editions of Martius' Historia Naturalis Palmarum Compared. Kew Bull 37: 91-116.

Greuter, W. et al. 2000. International Code of Botanical Nomenclature (St Louis Code). Konigstein. Koeltz Scientific Books. Art. 13

Martius, C.F.P Von. 1838. Historia Naturalis Palmarum. Munich. III: 119.

Miquel, F.A.G. 1851. Plantae Junghuhnianae. Van Landbouw. 163-165.

Rhumpius, G.E. 1741. Herbarium Amboinense 1. Amsterdam. Meinard. Uytwerf.

Saw, L.G. 1997. A Revision of Licuala (Palmae) in the Malay Peninsula. Sandakania 10:1-95.

Saw, L.G., Dransfield, J. \& Keith-Lucas, D.M. 2003. Morphological diversity of the genus Licuala (Palmae). Telopea 10: 187-206.

Uhl, N.W. \& Dransfield, J. 1987. Genera Palmarum. Lawrence. Allen Press.

Whitmore, T.C. 1973. Palms of Malaya. London. Oxford University Press. 67-70.

Wurmb, F.V. 1780. De Doorn Rolpalm. Verhandelingen van het Bataviaasch Genootschap der Kunsten en Wentenschappen 2: 469-474. 